\title{
An Analysis of Spoken and Written Errors Committed by the Tenth- Grade Students of SMA Negeri 1 Kuta
}

\author{
I.B.G. Phalaguna', I Nym. Adi Jaya P. ${ }^{2}$, Ni Md. Ratminingsih ${ }^{3}$ \\ ${ }^{123}$ English Language Education, Post Graduate Program, Universitas Pendidikan Ganesha, Singaraja, Indonesia \\ e-mail: ibphalaguna@gmail.com, jaya.putra@pasca.undiksha.ac.id, \\ made.ratminingsih@undiksha.ac.id\}@pasca.undiksha.ac.id
}

This study aimed at a) investigating the types of speech and written errors committed by the tenth-grade students of SMA Negeri 1 Kuta; b) investigating the sources of errors committed by the tenth-grade students of SMA Negeri 1 Kuta in speaking and writing. The subject of this study were the students of X science VII class. This class which consisted of 33 students; 16 males and 17 females, was chosen through purposive sampling. The data were collected through speaking test and writing test which were analyzed descriptively. The results indicated that, first, there were 438 speech error found, consisted of anticipations (2), perseverations (2), transpositions (14), substitutions (163), deletions (189), additions (67), and haplologies (1). Meanwhile, in writing, there were 772 errors found which consisted of grammar (623) syntax (56) dan mechanic (93). Second, the sources of errors in students' speaking and writing were interlingual and intralingual (overgeneralization, ignorance of rule restriction, incomplete application of rules, false concept hypothesized. These findings have an important contribution to EFL teaching, specifically on teaching speaking and writing.

\section{Keywords: descriptive text, error analysis, speaking, writing}

\section{INTRODUCTION}

It is important to master the four basic skills in order to be able to communicate effectively using the target language. Receptive skills of listening and reading allow recognition of language input and help comprehension, whereas productive skills of speaking and writing provide production of language forms to convey messages (Mundhe, 2015).

Nowadays, spoken and written interaction are being given a great deal of attention as it is essential in the communication process. According to Shumin (2002), learning how to speak and write in a foreign language, means knowing about its grammar and semantics and how to interact like a native speaker in communication process. It is because speaking and writing require using specific skills and strategies in communication. Therefore, EFL learners should be explicitly instructed and practiced to speak fluently and write properly.

However, learning a foreign language cannot be separated from mistakes and errors. They always occur in the process of learning because they are an inseparable part of the learning process. This phenomenon caught the behaviorists' attention who viewed error as a symptom of ineffective teaching or as evidence of failure. In fact, errors are not always bad. They are rather crucial parts and aspects in the process of learning a language. They may provide insights into the complicated processes of language development as well as a systematic way for identifying, describing and explaining students' errors. Errors may also help to better understand the process of second and foreign language acquisition (Jabeen, 2015). Similar with the previous studies mentioned above, this study emphasized on error analysis as well. However, this study did not deal with one competency only. Instead of just analyzing either writing or speaking, this study focused on analyzing both. Not to mention, these two competencies are really important for the students to possess in this globalization era.

In addition, the classification of errors in this study was different from the previous studies. The previous studies classified the types of errors in speaking and writing based on Dulay, Burt, \& Krashen's (1982) theories. Yet, this study tried to analyze the speech and written errors committed by the students from different perspectives. In this case, the theories of Dell \& Reich (1980) on slip of tongue and Darus \& Ching's theories (2009) on written errors were applied. 
SMA Negeri 1 Kuta was chosen as the setting of this study because this school is located near the tourism objects in which provide the students better exposure to learn English as a foreign language. Even though this school has got a great English exposure from the tourism object, it could not be taken for granted that the students are clean from errors. Therefore, to prevent the same errors from happening in the eleventh and twelfth grades, a study on error analysis was necessary to be conducted.

In accordance with the research background above, this study focused on 1) analyzing types of speech errors, 2) classifying types of written errors, 3) investigating the sources of speech errors and 4) identifying the sources of written errors

\section{RESEARCH METHOD}

This study was a descriptive research which was analyzed by using qualitative method. There two instruments used to collect the data needed for this research. Those instruments were: voice recorder and portfolios. Voice recorder was used to record students' speech about descriptive text and analyze the students' speech errors. Meanwhile, portfolios were used to analyze students' written errors.

The data of this research were obtained through several steps. In the first meeting, the students or the subjects of the research were given a brief explanation about descriptive text. The aim of explaining descriptive text $t$ the students was to make sure that they did not make other types of texts. Afterwards, they were informed about what they were supposed to do in the second meeting.

In the second meeting, the students were asked to give an oral description about anything. They were free to choose their topics. The students' voices were recorded by using a voice recorder while they were presenting or describing the topic.

The next step was obtaining students' writing. In this step, the students were asked to write down a descriptive text with a free topic too. However, they had to describe something different from their speaking in the previous meeting.

In analyzing the data, there were several steps that which were taken by the researcher. Those steps were: 1) classifying the types of error, 2) conducting expert judgement (interpreter), and 3 ) interpreting the sources of errors

\section{FINDINGS AND DISCUSSION}

From the result of analysis, it was found that the tenth-grade students of SMA Negeri 1 Kuta, still find it difficult to speak and write properly in English. It can be seen from the numbers of errors committed by them. In speaking, they committed as many as 436 errors in total. Meanwhile, 772 errors were found in their writing. The description and explanation of each error can be seen below.

Table 1. Students Speech Errors

\begin{tabular}{l|l}
\multicolumn{1}{c|}{ Type of Speech Error } & \multicolumn{1}{c}{ Number of Error } \\
\hline Anticipations & 2 \\
\hline Perseverations & 2 \\
\hline Blends & - \\
\hline Transpositions & 14 \\
\hline Substitutions & 163 \\
\hline Deletions & 189 \\
\hline Additions & 67 \\
\hline Haplologies & 1
\end{tabular}

Table 1 and above show that deletions (189) was the most error committed by the tenthgrade students of SMA Negeri 1 Kuta in their speaking. It proved that most students left out something in their sentences when they speak in English. The deletions committed by the students in their speaking were mostly in the form of verbs. It was the biggest problem faced by the students when they spoke English. The omission of verbs occurred because of the incomplete understanding or the students' assumed that their sentences were already correct. 
Not only verbs, most of the students also failed to use correct articles and prepositions in their speaking. Sometimes they omitted the required articles and prepositions, sometimes they added them in their speech where they were not needed. Therefore, it was no wonder if article and prepositions errors became the second and the third most committed errors after verb errors.

The next most committed error after deletions was substitution errors (163). According to Dulay et al. (1982), misformation/substitutions is a kind of error committed by the learners in which they used the wrong form of a structure or morpheme. In this kind of error, the students had mostly misused verbs, pronouns and prepositions.

Statistically, this result of analysis shows quite identical numbers with the one committed by Danurwindo (2014). In his study, Danurwindo conducted a similar research on error analysis which aimed to analyze the types of grammatical errors committed by the students of second semester of IAIN Tulungagung in speaking skill. There were 30 students who became the subjects of the research. The result of the analysis showed that the highest frequency of error was misformation which the number of percentage achieves $47 \%$. The second frequency of error was omission which the number of percentage achieves $42 \%$. The third frequency of error was addition which has number $8 \%$. The last frequency of error was misordering which has low number $3 \%$.

Deletions (omission) and substitutions (misformation) were not the most committed error in this study only. Previously, in 2016, Safrida \& Kasim also conducted a research on analyzing students' errors in speaking and the most dominant errors conducted by the students were in the form of omission and misformation error as well. So, it can be concluded that the biggest problems faced by the students in their speaking were still the same year after year.

However, in this study, there were other types of error found in students' speeches which did not exist in the previous studies. Those errors were anticipations and haplologies. According to Dell \& Reich (1980), anticipations occur as the initial consonant of the first word is replaced by the initial consonant of the latter word. Meanwhile haplologies are the omission of one occurrence of a sound or syllable which is repeated within a word.

Meanwhile, the types of error in writing can be seen in the following table.

Table 2. Students' Written Error

\begin{tabular}{l|l}
\multicolumn{1}{c|}{ Type of Speech Error } & \multicolumn{2}{c}{ Number of Error } \\
\hline Grammar & 623 \\
\hline Syntax & 56 \\
\hline Mechanics & 93
\end{tabular}

As what can be seen on the table 2 above, the types of errors and the total number of the errors committed by the students in their writing were more than in speaking. It was because the students tended to write more than what they said. And again, verb error became the most committed error. It means that the use of verbs was really a big deal for the tenthgrade students of SMA Negeri 1 Kuta both in speaking and writing. Not only verbs, the students also had problems dealing with subject-verb agreement (the second most committed error) and article (the third most committed error) in their writing.

After conducting interpretative description, it was found that the sources of students' speech and written errors were interlingual errors (the influence of mother tongue) and intralingual errors (overgeneralization, ignorance of rule restriction, incomplete application of rule, false concept hypothesized).

According to Erdogan (2005) and Kaweera (2013), interlingual interference are the errors produced because of the influence of learners' L1. In this case, the learners do not realize that their native language structure is different from the target language. Meanwhile, intralingual errors which are also known as "developmental errors" are errors which happen during the learning process of the second language at a stage when the learners have not really acquired the knowledge (Richards, 1974). 
The result of analysis also found that most of errors in speaking and writing were caused by intralingual interferences (developmental). It means that the biggest problem faced by the students in learning English was not because of their mother tongue (Bahasa Indonesia), but the students' understanding about the target language (English) was still poor.

The sources of errors in this study was quite similar with the study conducted by Cahyanti (2015). She conducted a research entitled "An error analysis on students' speaking based on communicative effect taxonomy (A descriptive study of the eleventh-grade students of SMA N 1 Sambungmacan Sragen in the academic year of 2013/2014)". The result of the analysis of the twenty-six students' spoken corpus found that there were numbers of error based on communicative effect taxonomy which were then classified into local and global errors. The causes of error committed by the students in this study basically came from interlingual transfer which was caused by the interference of their mother tongue and intralingual transfer which was a negative transfer within the target language (English).

It was also similar with the study conducted by Tandikombang, et al. (2016). The research which was conducted to the fourth-semester and the sixth-semester students of UKI Toraja in the academic year 2014/2015 reveal that the most frequent errors in both levels are errors in verbs; and that most of the errors are due to overgeneralization and the ignorance of the rule restriction.

\section{CONCLUSION AND SUGGESTIONS}

Based on the findings and the result of the analysis, it was found that the tenth-grade students of SMA Negeri 1 Kuta in the academic year 2017/2018 committed as many as 438 speech errors. These errors were classified into seven types of speech errors; anticipations (2), perseverations (2), transpositions (14), substitutions (163), deletions (189), additions (67), and haplologies (1). Among those errors, deletion error was the most committed error in speaking.

Meanwhile, in writing, the errors committed by the students were as many as 772 , which were categorized into 3 main types; 623 errors in the use of grammar, 56 syntax errors and 93 mechanic errors. Those types of errors were sub-divided again into smaller parts. From the sub-types of errors, it was found that the most committed error was verb error.

The result of analysis also found that there were two sources of students' errors; interlingual interference and intralingual interference. From these two sources of errors, most of students' speech errors in this study was caused by intralingual interference.

Similar with speech errors, students' written errors were also caused by interlingual and intralingual interferences. In this study, the students' written errors were mostly caused by intralingual interference.

Thus, for the suggestion, the teacher needs to give more emphasis on correcting the students' deletions errors since these kinds of errors were the most dominant errors committed by the students in their speaking. However, it does not mean that the teacher can ignore the other kinds of errors committed by the students. In general, all kinds of errors need treatment to avoid them from happening again and again.

The same goes for teaching writing. Since the most written errors were in the form of verb, the teacher needs to give more emphasizes on the use of verbs. Most importantly, however the teacher is expected to find new and better teaching strategies for teaching writing.

The role of interlingual and intralingual interferences could never be avoided in EFL teaching and learning. They can be minimized though. In speaking, interlingual and intralingual interferences can be decreased by giving the students enough chances to interact with native speakers. Not to mention, SMA Negeri 1 Kuta is located near tourism objects and it has great exposures to learn English.

Similar with speaking, to minimize the influences of interlingual and intralingual interferences in writing, the teacher needs to give the students enough time to practice writing. The more they practice, the better they will write. The teacher also needs to find a good teaching technique for teaching writing because writing is complex 


\section{REFERENCES}

Cahyanti, I. (2015). An error analysis on students' speaking based on communicative effect taxonomy (A descriptive study of the eleventh-grade students of SMA N 1 Sambungmacan Sragen in the academic year of 2013/2014) (Master's Thesis, Universitas Sebelas Maret, Sragen, Indonesia). Retrieved from https://eprints.uns.ac.id/17608/.

Danurwindo, F. (2014). Grammatical error analysis in speaking of the second semester English students of IAIN Tulungagung academic year 2013-2014 (Master's Thesis, IAIN Tulungagung, East Java, Indonesia). Retrieved from http://repo.iaintulungagung.ac.id/484/7/JOURNAL.pdf

Darus., S \& Ching K. H. (2009). Common errors in written English essays of form one Chinese students: A case study. European Journal of Social Sciences, 10, 242-253. Dell, G.S., \& Reich, P.A. (1980). Toward a unified model of slips of the tongue. In V.A. Fromkin (Ed.), Errors in linguistic performance: Slips of the tongue, ear, pen, and hand (pp. 273286). New York: Academic Press.

Dulay, H., Burt, M., \& Krashen, S.D. (1982). Language two. New York: Oxford University Press

Erdogan, V. (2005). Contribution of error analysis to foreign language teaching. Mersin Üniversitesi Eğiitim Fakültesi Dergisi, 1(2), 261-270.

Jabeen, A. (2015). The role of error analysis in teaching and learning of second and foreign language. Journal of Macro Institute, 1(2), 2377-1356. doi:10.5296/elr.v1i1.8189.

Mundhe, G. B. (2015). Teaching Receptive and Productive Language Skills with The Help of Techniques, 1(2), 2454-3454. Retrieved from http://www.puneresearch.com/media/data/issues/55fbb8b0dd37d.pdf

Richards, J. C. (1974). Error Analysis: Perspectives on second language acquisition. London: Longman

Safrida \& Kasim, U. (2016). Grammatical errors: An analysis in speaking produced by EFL undergraduate students. Research in English and Education (READ) Journal, 1(1), 2528-746X.

Shumin, K. (2002). Factors to consider: Developing adult EFL student speaking abilities. In J. C.Richards \& W.A. Renandya (Eds.), Methodologyin language teaching: An anthology of current practice (pp.204-211).Cambridge: Cambridge University Press. http://dx.doi.org/10.1017/CBO9780511667190.028

Tandikombang, M., Atmowardoyo, H, Weda, S. (2016). Grammatical Errors in the English

Translation Made by the Students of English Study Program of UKI Toraja. English Language Education Graduate Program: State University of Makassar, Indonesia 